\title{
Birthday Barbie
}

\author{
Janis Butler Holm
}

\begin{abstract}
Dans ce poème en prose, un groupe de garçons (des hommes?) convient leurs poupées Barbie (leurs petites amies?) à une fête d'anniversaire. Ils rivalisent pour savoir laquelle est la meilleure (la plus sexy). L'un des garçons l'emporte, et c'est alors que les autres chahutent et en viennent aux prises, tandis que toutes les Barbie restent immobiles à contempler leur avenir:
\end{abstract}

Conversation stopped when David arrived with his Barbie. She was a real doll, ice-blonde hair in sexy curls, Bob Mackie gown a rainbow wonder, pumps the very highest of fuck-me killers, with minuscule silk flowers on the toes. It was clear that David's Barbie was going to win. The other boys, crestfallen, proceeded to gulp their drinks. They talked more loudly, sneered at the birthday games, and began to ignore their own Barbies. Soon they were picking fights, shouting and throwing food. They started to punch each other, hard. In a corner, the Barbies stood together, immobilized, as fists flew and cake hit the walls. What could they do? What could they say? They stood stiffly, unblinking, staring into their certain futures. 


\section{Memo to Barbie: Re the Breakup}

Ce poème en prose, sous la forme d'un mémorandum, est une série de consignes à l'attention de Barbie pour lui indiquer comment gérer sa séparation d'avec Ken. Ses patrons lui conseillent de ne pas parler de cet événement. Elle devra aussi se préparer à faire face aux remarques désobligeantes au sujet de Ken et d'autres poupées mâles, sans oublier la réaction du public face à sa séparation. Ils lui demandent enfin de se transformer et de se vendre - faute de quoi...

1. Let $u s$ make the announcement. Let us explain that you and Ken will always be good friends. Let us suggest that his replacement is waiting in the wings. Say nothing about the situation to anyone.

2. Prepare for jokes about mid-life crises and the "perfect plastic couple"- how the bridal gown is yellowing in your closet, how Ken doesn't have the equipment, how he's worn more costumes than the Village People, how the sex tape must have proved too much. Be ready for crude remarks about Chuckie, the Power Rangers, GI Joe, and trolls. Smile and say nothing.

3. Prepare for the moral outrage of those who don't like change: "she's failed as a role model," "separation shouldn't be a publicity stunt," "I remember when Barbie meant something," "isn't one Britney enough?" Do not address such comments. Do not defend yourself.

4. Get a makeover. Recall that you first won hearts in a swimsuit, and tell yourself you can do it again. Think California. Think beach bunny. Find the tiniest bikini top possible. Smile sunnily during the photo shoots.

5. Start selling yourself. Bring in the money, now. Remember what you owe us: we made you, we own you, there are younger ones dying to take your place. Don't tell us you're tired. Get out there and do your job. Think profits. Think performance. Think it's your last chance, Bitch. 